\title{
TRENDS IN VERTEBRATE PESTICIDE CONTAMINATION OF WILDLIFE
}

\author{
G.R.G. WRIGHT, L.E. BROWN, C.D. RADFORD and C.T. EASON \\ Landcare Research, P.O. Box 69, Lincoln, Canterbury
}

\begin{abstract}
Vertebrate pesticides are used throughout New Zealand in both wild animal control and threatened species management. Non-target impacts has always been of concern with the use of these pesticides and much research has been conducted on the environmental impacts of 1080 . However, during the last two years, the focus of vertebrate pesticide concern has centred on the persistence of brodifacoum in the environment, so that it now rivals 1080 for the number of samples tested in the vertebrate pesticide testing laboratory. During this period, 419 samples were tested for brodifacoum, while 430 were tested for 1080, including 361 water samples from the monitoring of 1080 pest control operations. Data now exist for brodifacoum concentrations in 28 bird species with the highest concentrations found in morepork $(3.4 \mathrm{mg} / \mathrm{kg})$, weka $(2.3 \mathrm{mg} / \mathrm{kg})$ and chaffinch $(2.3 \mathrm{mg} / \mathrm{kg})$. There is also data for 12 species of mammal, where the highest concentrations were found in rat $(14.7 \mathrm{mg} / \mathrm{kg})$, pig $(2.4 \mathrm{mg} / \mathrm{kg})$ and weasel $(2.3 \mathrm{mg} / \mathrm{kg})$ tissues.
\end{abstract}

\section{ORGANOPHOSPHATE TOXICITY IN WOLF SPIDERS (LYCOSIDAE): AN EVALUATION OF SUBLETHAL RESPONSES}

\author{
S. VAN ERP ${ }^{1}$, L.H. BOOTH ${ }^{2}$, R. GOONERATNE ${ }^{1}$ and K. O'HALLORAN ${ }^{2}$ \\ ${ }^{1}$ Department of Animal and Food Science, Lincoln University, P.O. Box 84, Christchurch \\ ${ }^{2}$ CENTOX, Landcare Research, P.O. Box 69, Lincoln
}

Wolfspiders (Lycosa hilaris) are abundant in pasture throughout the Canterbury region. The activity of cholinesterase (ChE) and glutathione S-transferase (GST) were assessed in wolfspiders as biomarkers of organophosphate contamination in agroecosystems. Spiders were exposed to fieldsimulated rates of chlorpyrifos and diazinon under laboratory conditions. Males were found to be more sensitive, in terms of survival, compared to females. However, gender-specific differences in $\mathrm{ChE}$ and GST were not evident. Gluthathione S-transferase activity was not affected by either pesticide. Cholinesterase activity in male spiders was inhibited by $40 \%(\mathrm{P}<0.001)$ and $86 \%(\mathrm{P}<0.001)$ by diazinon and chlorpyrifos, respectively. The $\mathrm{ChE}$ response was further investigated under field conditions, where spiders were enclosed in mesocosms located on diazinon-sprayed pasture. Three hours after spraying, 20 spiders (10 control and 10 treated) were placed onto replicate plots. Twentyfour hours later mortality was recorded and survivors were collected for subsequent enzyme analysis. This process was repeated every 24 or 48 hours for 8 days. Twenty-four hours following pesticide application, mortality was $20 \%$ which corresponded to a significant inhibition in $\mathrm{ChE}(87 \%, \mathrm{P}<0.001)$ in the surviving spiders. ChE activity gradually returned to normal levels after 6 days following pesticide application. Cholinesterase activity in wolf-spiders shows a clear and sustained inhibition to a single application of organophosphate and has potential as a biomarker of contamination under field conditions. 